\title{
The Role of Political Satirical TV Programs during Political crises
}

\section{DR. MEVIVE A8OLAWAFI,ASSISTANT PROFESSOR AT FACULTY OF MASS COMAUNICATION, MISR INTERMATIONAL UNIVERSITY}

\section{Abstract}

Satire is a technique that laughs at particular people or objects in order to point out problems in an attempt to bring about change. Politicians, social structures and narrow-minded or biased public opinions and systems are the most common targets of satirical compositions. Satirists (people who compose satire) often use techniques such as irony, exaggeration, sarcasm (Antonyms), metaphors and sketches in order to ridicule their subjects.

The paper focuses on Bassem Youssef's show Al Bernameg (The Program), which regularly criticizes public figures. It has become a sensation after it was launched online in the aftermath of Egypt's revolution. Political humor excited the protests in gaining new momentum, with a new generation of satirists using comedy to speak truth to power. Bassem Youssef used the clips to create a mock Arabic newscast posted on YouTube, homage to Comedy Central's "The Daily Show" of Jon Stewart. Al Bernameg of Bassem Youssef is similar to The Daily Show of Jon Stewart in merging entertainment with news. It is notably news satire format and the talk show format.

This paper tries to answer many questions: whether this political satirical talk show will help flourish a new genre in Egyptian media? And what exactly is the political content of the program? Many theories as critical discourse analysis approach of Fairclough (2003), Grice's conversation maxims (1975), and Entman's framing of media effects (2004) are used in the satirical analysis of the texts of " $\mathrm{Al}$

\section{Bernameg".}

\section{Introduction}

Satire acts as a "relief theory" model of humor in periods of political crisis. There is a multi-functional characteristic of satirical discourse or TV programs when it is considered as a model of humor. In this case humor acts as a social lubricant, venturing ice-breaking goodwill and demonstrating ability to laught.Humor may act also as a "fire-grained social sandpaper", because comedy makes frankness less threatening and conveys criticism less contentiously.

(Basu 1999:390-394).

Satirical discourse suffuses the general humor resources of modem societies and cultures. It is not an alien form of humor, not something remote from everyday social interaction, but is much part of the communicative competence of adult participants as puns, jokes and funny stories.

This paper traces the works of linguists, psycholinguists, sociolinguists, philosophers and media experts to analyze several satirical texts of TV programs to pick out the satirical techniques as exaggeration, incongruity, parody and reversal and prove how much they influence the attitudes of the people within a social system. Framing theory of Entman (2004) is highlighted in this study to show that the framing has been particularly useful in understanding the media role in political life especially in case of crises. (1)

In Egyptian media, many satirical TV programs appeared lately due to the rising of depression and chaos among all society categories as a result of increase of violence, suppression and dissatisfaction with the ruling system after high aspirations resulting from the January revolution 2011 .

\subsection{Objective of study}

This research paper seeks to study special discourse and pragmatic features that characterize this popular form of contemporary humorous discourse as is manifest in several satirical TV programs as Bassem Yousef"Al Bernameg" ,Hany Ramzy"El Lila ma3a Hany" ,Azab Show and others. The focus in this analysis is on the content and language of one of these programs Bassem Yousef "Al Bernameg"and to assess the degree of effectiveness of satirical techniques on the target audience. Therefore the satirical and linguistic tools used in these programs are measured and analyzed. Discourse or text of these programs is understood in this instance as a level of language organization that arises out of the interaction between text and context.

This paper tends to answer the following questions:

- What is the role of language in political satirical TV programs?

- What are the most effective and persuasive satirical techniques used in such programs?

- Is satirical discourse a discursive practice?

- How can we assess the degree of persuasiveness of a satirical discourse?

- What is the role of satirical discourse during political turmoil?

- What is the effect of framing theory on the attitudes of audience?

\section{I.2. Review of literature}

Simpson (2003) argued that:

"Sntirical discourse is a discursive practice as embodying three subject positions which are the satirist (producer of a text), the satire (an addressee whether reader, viewer or listener) and the satirized (the 
target attacked or criticized in the satirical discourse).Two of these participants (the satirist and the satire) are ratified within the discursive event. However, the third entity, the target, is ex-colluded discourse participant who may be a person or an idea or object."

Simpson (2003) elaborated that:

"A satirical text can function, in terms of its linguistic propertics, as an instantiation of a discourse prime. The prime in this sense is an "echoic" utterance to the extent that it is predicated on someone else's discourse, but over which ironic distance is placed through the repositioning of the ostensible speaking source of the text. Several of the compositional techniques used in satirical can be analogical to metaphor and metonymy. Connections between the features of discourse that expand the prime on the one hand and the dialectic on the other are often established ,embellished and sustained by puns and other forms of word-play. These two bivalent lexico-grammatical devices help in binding together the two colliding elements of textual pattering which are referred to as stylistic hooks. It is the dissonance between the domains of prime and dialectic which creates an interpretive -pragmatic framework for satire and brings about style -shift necessary to place the viewer or listener on a satirical footing."

As Alberti (2003) suggests that satire is a critical but humorous commentary on the social pressure to follow traditional values that define what it means to be part of mainstream culture in a society. By challenging what is acceptable, satire carries out what French historian and philosopher Michel Foucault calls resistance (Rabinow, 1984).

For Foucault (1990), resistance calls into question what is accepted as correct, and highlights what has been declared off limits by society, religion, education, government, etc. as inappropriate, unacceptable, wrong, abnormal, or false (Pickett 2006). In other words, satire is a form of resistance. Within Foucault's framework, resistance seeks to undermine power, which is the overall objective of satire (Pickett, 2006).

It is in this unique role that satire can function as a means of fighting back against the pressures of socicty, laws, and institutions, and makes satire a noteworthy form of communication that can be explored further. The humorous nature of satirical works, such as Bassem Yousef's "Al Bernameg", enable people to easily participate in the small act of resistance that is created when criticism provokes laughter, reminding people that alternatives can be created and possibly providing a spark of inspiration for a better future. In this sense as resistance, the satire of Bassem Yousef's "Al Bernameg" carries on the longstanding desire for freedom that has marked the use of satire by giving a voice to the discourses that have been put down and silenced by society, politics, and culture. Although Bassem Yousef's "Al Bernameg", is certainly good for laughs, the satirical discourses in the film also present a clear example of Foucault's concepts of power and resistance that can help non-Westerners understand these important ideas from Foucault have influenced Western academic research for more than thirty years. Thus, the objectives of this study were to identify the satirical discourses present in the film, and then demonstrate how those discourses illustrate Foucault's concepts of power and resistance.

\section{II.Theorctical framework}

The emphasis across the discipline of humorous or satirical discourse is based on studies of language and mass communication.

\section{II.I.Grice's Corporative Principle of} conversation analysis

In social science generally and linguistics specifically, the cooperative principle describes how people interact with one another.

As phrased by Grice (1975), who introduced it, it states:

"Make your contribution such as it is required, at the stage at which it occurs, by the accepted purpose or direction of the talk exchange in which you are engaged."

Though phrased as a prescriptive command, the principle is intended as a description of how people normally behave in conversation.

Listeners and speakers must speak cooperatively and mutually accept one another to be understood in a particular way. The cooperative principle describes how effective communication in conversation is achicved in common social situations.

The cooperative principle can be divided into four maxims, called the Gricean maxims, describing specific rational principles observed by people who obey the cooperative principle: these principles enable effective communication. Grice proposed four conversational maxims that arise from the pragmatics of natural language. The Gricean Maxims are a way to explain the link between utterances and what is understood from them. (2)

II.2. Foncaultian Epistemology of Resistance (1990)

Satirical programs in TV are considered a kind of resistance against over use or unfair use of power during political turmoil and state absence as well as ignorance of people's rights. Therefore I found the theory of resistance and power of Foucault (1990) is applicable on my study of the most effective content or text of such type of TV programs that appeared and flourished lately in Egypt.

Foucault(1990) said that there is interrelation between power and resistance and struggles of mobs to fight dictatorship rules must be traced in reviewing of satirical political talk shows as a an indicator of their success in their war against in. justice and over use of power. Such programs create a unique kind of bond between the satirist and the audience. When a joke fails. listeners usually feel like rejecting the joke teller and often do. Therefore the language used in the program to. gether with the novelty of the satirical techniques participates in the success of the program.

1I.3.Critical discourse analysis approach of Fairclough $(1992,1995,2003)$

Tcxts, language. communication should therefore always be considered in their social context, they both shape and are informed by wider processes within society. In this manner texts do not merely passively report upon the world, but they imbue it with meaning. fabricate it, shape per- 
spcctives and call the world into being. The broad term discourse can be employed in these circumstances as it refers to the various ways in which communication between people is achieved. Discourse can be considered as an 'active relation to reality' (Fairclough 1992: 41). Fairclough (2003: 26) has delineated three characteristics of discourse which describe its operation within social life, as 'part of the action.' These are;

- Genres (ways of acting)

- Discourses (ways of representing)

- Styles (ways of being) (3)

Fairclough (1995: 132) argued that in order to study a conversational text in the field of media, the researcher needs:

'to systematically explore often opaque relationships of causality and determination betwcen (a) discursive practices, events and texts, and (b) wider social and cultural structures, relations and processes; to investigate how such practices, events and texts arise out of and are ideologically shaped by relations of power and struggles over power'

In my study, it is noticeable that certain discourses are stronger in effect on audience than others. One of these effective discourses is the satirical discourse of such political TV programs.

\section{II.4.Framing of media effects}

This paper focuses on a review of the meaning of the concept of framing, approaches to studying framing, and the effects of framing on public opinion. After defining framing and framing effects, I articulate a method for identifying frames in communication and a psychological model for understanding how such frames affect public opinion. It also discusses the relationship between framing and priming, outline future research directions, and describe the normative implications of framing.

Entman (2004) argued that:

"There are two classes of framing, substantive and procedural. Substantive frames perform at least two of the following basic functions in covering political events, issues, and actors:

- Defining effects or conditions as problematic.

- Identifying causes.
- Conveying a moral judgment.

- Endorsing remedies or improvements.

\section{III.Methodological Framework}

\section{III.1.Data collection}

I downloaded five episodes of Bassem Yousef's "Al Bernameg"from You Tube. I chose these episodes because they were so effective on the public and included satirical discourses that can be analyzed in this paper. The study focused on assessing how satire functions as resistance to power by looking at the forms and techniques of satire that were used to deal with the discourses in the program.

\section{III.2.Data analysis}

This study is divided into two levels of analysis: a survey of all the most effective linguistic techniques used in the satirical political talk show "Al Bernameg " by Bassem yousef on one level and on the second, it presents an assessment of the degree of persuasiveness of the satirical techniques used other than language in the program. The research also puts in frames the words and images used in the program other than the rest of news to evaluate their capacity to stimulate either support or opposition from the side of the target audience of such show. This capacity can be measured by cultural resonance and magnitude, The satirist in this case uses words and images highly salient in the culture, which I can say noticeable, memorable ,understandable, and emotionally charged. The more resonance and magnitude, the more likely the framing is to evoke similar thoughts and feelings in large portions of audience. The paper reviews the criteria through which this type of program moved from being a You Tube format to an on -air or live most popular talk show not only in Egypt but in all over the Arab world.

Bassem Youssef is a media phenomenon in Egypt. His YouTube show remains the highest viewed in Egypt, with well over 33 million views, and it's the first and only Arabic YouTube channel in the Middle East with eight official commercial ads. But with the steep financial investment that the new formal will de- mand, Youssef is unsure whether he will stay on air talk show after the end of the political crisis that Egypt witnesses and will this new TV format survive hereafter or not.

III.3.Audience Research

I conducted an audience research on a random sample of 200 people of different social and cultural levels to assess the role of Political Satirical TV Programs on different categories of society during the political crises and to allocate which is more effective technique or persuasion: the linguistic factor or the satirical techniques as well as the frame or degree of effectiveness on the society behavior or attitude.

\section{Operational definition of variables} Table One

The most heavily watched Political Satirical TV Program.

\begin{tabular}{|l|l|l|}
\hline $\begin{array}{l}\text { Name of Satirical } \\
\text { Program }\end{array}$ & Frequency & Percentage \\
\hline $\begin{array}{l}\text { 1- Bassem Yousef 's } \\
\text { "Al Bernameg" }\end{array}$ & 170 & $85 \%$ \\
$\begin{array}{l}\text { 2- Hany Ramzy 's } \\
\text { "Al Lila ma3a Hany" } \\
\text { 3- Azab Show }\end{array}$ & 10 & $5 \%$ \\
$\begin{array}{l}\text { 4- lbrahim Essa 's } \\
\text { "Hunna Al Qahera" }\end{array}$ & 10 & $5 \%$ \\
\hline
\end{tabular}

\section{Table Two}

The measurability of effectiveness of satirical techniques in such programs.

\begin{tabular}{|c|c|c|}
\hline $\begin{array}{l}\text { Measuring the most } \\
\text { effective technique } \\
\text { in such satirical } \\
\text { programs }\end{array}$ & Frequency & Percentage \\
\hline $\begin{array}{l}\text { 1- Anchor's language } \\
\text { and performance. }\end{array}$ & 200 & $100 \%$ \\
\hline 2- Puns and jokes. & 100 & $50 \%$ \\
\hline $\begin{array}{l}\text { 3- Comic video clips } \\
\text { from other channels. }\end{array}$ & 150 & $75 \%$ \\
\hline $\begin{array}{l}\text { 4- Mimicry of OF- } \\
\text { ficials and President. }\end{array}$ & 150 & $75 \%$ \\
\hline $\begin{array}{l}\text { 5- Funny clips mock- } \\
\text { ing government. }\end{array}$ & 150 & $75 \%$ \\
\hline
\end{tabular}


Table Three

The measurability of the role of political satirical programs during political crises.

\begin{tabular}{|l|l|l|}
\hline $\begin{array}{l}\text { Role of Political Sa- } \\
\text { tirical Programs } \\
\text { during this political } \\
\text { crisis }\end{array}$ & Frequency & Percentage \\
\hline $\begin{array}{l}\text { 1-A break for sup- } \\
\text { pressed people. } \\
\text { 2- Unveiling the er- } \\
\text { rors of government } \\
\text { and presidency. }\end{array}$ & 10 & $5 \%$ \\
$\begin{array}{l}\text { 3- Expression of } \\
\text { public discontent } \\
\text { and a call for change } \\
\text { from the part of gov- } \\
\text { ernment. }\end{array}$ & 180 & $90 \%$ \\
$\begin{array}{l}\text { 4- Only for en- } \\
\text { tertainment. }\end{array}$ & 15 & $7.5 \%$ \\
\hline
\end{tabular}

Table Four

The measurability of continuity of such programs after the end of political crises.

\begin{tabular}{|l|l|l|}
\hline $\begin{array}{l}\text { Agreement of the } \\
\text { continuality of such } \\
\text { type of programs af- } \\
\text { ter political crises. }\end{array}$ & Frequency & Percentage \\
\hline $\begin{array}{l}\text { 1-yes } \\
\text { 2- No }\end{array}$ & $\begin{array}{l}200 \\
\text { zero }\end{array}$ & $100 \%$ \\
\hline
\end{tabular}

Table Five

The prefer ability of watching such programs than normal talk shows.

\begin{tabular}{|l|l|l|}
\hline $\begin{array}{l}\text { Prefer ability of } \\
\text { watching such sa- } \\
\text { trical programs than } \\
\text { normal talk shows. }\end{array}$ & Frequency & Percentage \\
\hline 1-yes & 180 & $90 \%$ \\
2- No & 20 & $10 \%$ \\
\hline
\end{tabular}

\section{Results}

- In table one, it was proved that the majority of age categories in the Egyptian society watch Bassem Youscf's "Al Ber- nameg $(85 \%)$ while the rest of my sample (15) \% watch other satirical programs which means that the general appetite now in the case of political crisis and economic recess is to like such type of programs.

- In table two, it is clear that language of the satirist plays a vital role in affecting and influencing the target audience, and then comes the comic video clips from other TV channels which helps in enhancing the degree of persuasion and confirms the reality of such error in the performance of either the President or the government. The mimicry of government officials and the President is considered a way of making fun of their wrong acts and weird as well as unaccepted behavior by the civil associations as if it is a watch dog of their activities.

- In table threc, the role of political satirical programs during the state of political chaos and disorder as well as absence of the state or government is clear if the reasons bchind are proved .It is shown through the survey of the viewpoints of the audience of different social levels, age and gender that such programs are influential as a means of expression of public discontent and a call for change from the part of government (90\%).However, $75 \%$ of the target audience considered them as a way of unveiling the errors of government and presidency. Only $7,5 \%$ of the sample are watching such programs for entertainment only which means or it is an indicator of the increase in the rate of awareness of the mobs even the ordinary people.

- In table four , a very significant indicator is detected which is the fact that such satirical programs became a new trend in the Egyptian as well as Arab media so $100 \%$ of the sample agreed that these programs will continue after this political crisis is over. They have become an effective technique of expression of discontent and suppression. It is a method of flagrant unveiling of the whole truth of the regime and mobilization of the emotions of the nations towards revolting and concrete action on the ground.

- In table five, $90 \%$ of the sample proved that they prefer to watch such satirical political programs than the ordinary or normal talk shows which became boring and dull due to the fact that they repeat the same scenes of anger and discontent of the mobs in a useless process of protests and repeated guests who reiterate the same words in every TV channel without reaching any resolution or consensus on a solution by all concerned parties.

\section{IV.Discussion}

Discourse framework (l)

"Al Bernameg" [The Progam], currently in its second season is credited with changing the landscape of media and comedy in Egypt, the Arab world's largest TV market. Bassem Yousef has become one of the country's most recognizable faces.

"Al Bernameg" follows the model laid out by The Daily Show with Jon Stewart has broken new ground in the Middle Eas with its penchant for mocking political figures and pointing out the flaws and hypocrisy of news outlets.

"Sarcasm empowers people, so that they can speak up against authority, whether they are a man of the state or a man of the cloth," Youssef says.

It's difficult to overstate the impact the show has had in its relatively short lifespan. But it's safe to say that nothing like it has ever been seen on Arab tclevision beforc. Youssef's second season has so far taken potshots at the elected Islamist government and the incrcasing polarization in Egyptian society, which Youssef belicves is partially fueled by the rise of religious satellite channels." Al Bernameg" has carved out a role for itself in Egypt's media landscape as a kind of gallekeeper, quick to reprimand shows for propagating deceit and fear-mongering.

In the 'Al Bernameg' studio, nothing is sncred, not even the president. By directing satire at the man himself - unthinkable during the Mubarak era - the show is taking full advantage of the hard won freedom of expression gained after the 2011 uprising when the so-called 'fear barrier' was broken.

If the theory of framing of Entman (2004) is applied on any of Bassem Yousef's episodes, it is proved that it is substantive frame as it defines the errors of the criticized object or person and sets remedies of the problematic issue through the satirical techniques expressed in the pro- 
gram. Therefore, procedural framing suggests evaluations of political actors'legitamacy, based on their technique, success, and representativeness.

Yousef told his audience in the opening segment, taped on that night that deadly clashes raged outside the presidential palace:

"What is happening to the people on the streets, and the deaths from both sides, are the responsibility of the person who says he is a president for the whole country." ما يحسدث للناس في الشوارع و الفتل علي الجيانبين

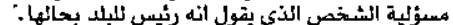
"ma ya7dos lil nas fi al shawari3 wa al qatl 3ala al ganibeen mas"uliyat al shakhs al lazi yaqool "inahu ra"ces lil balad bi7alha."

The show gocs on to make fun of a hastily arranged TV interview president Morsi conducted in an attempt to diffuse the backlash from his decree. In response to a question about the reason for his decree, the president launches into a monologue about Egypt and its blessings and asks the Egyptian to hug one another. Using fast forwarding visual and sound effects, Youssef makes fun of the incoherent 16 minute response which failed to answer the question.Youssef said :

"Morsi said in the interview, which was broadcast on the Mehwar television channel and conducted by television host Amr El-Lithy, Morsi's former media advisor on 25th of February 2013: It is the Egyptians who are ruling Egypt. I am a president for all Egyptians and the only one responsible for my decisions, which I negotiate with all factions,"

مـرسي فال في حديث مـاع علي قناة المحسور و اداره

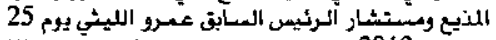

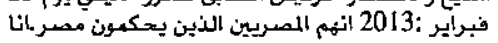

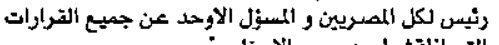

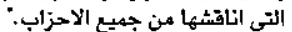

“ morsi qal fi 7adees moza3 3la qanat al me7war wa adarahu al muzee3 wa al mostashar al msabeq lil ra"ces morsi yoom 25 fibrayer 2013 : inahom al masriin al lazeen ya7komoon misr ana ra"ees likol al masriin wa al mas"ool al a"w7ad 3an gamee3 al qararat alati "unaqshha ma3a al "al a7zab."
Media discourse is a key public domain of language use for the sociology of language.

Also, Bassem makes fun of recent calls for civil disobedience in scveral governorates the president emphasized that calls for such action should be born from the people's will to express their opinions through peaceful means, and not because the movement is bullying people to do so.

Morsi said: "I plan to visit Port Said soon,"

"مرسي اعلن: انا سازور بورسعيد قريبا"

“ morsi " a3lan : Anà sa"zoor boor sa"eed qariban."

Demonstrators in Port Said have been conducting an ongoing campaign of 'civil disobedience,' which has led to the closure of most of the city's primary institutions including companies, factories, official authorities (including the local customs authority) and the East Port Said maritime port - for eight consecutive days.

"President Morsi further added that: I am not considering resigning because I am determined to carry out the responsibility handed to me by the people to the end of my four-year tcrm. I will continue and will not abandon this responsibility. I accuse the revolution's "enemies" of , not wanting to sce Egypt flourish."

الرئيس مرسي اذياف: انا مش بافكر في الاستقاله

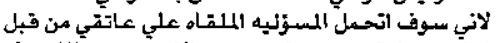

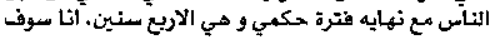

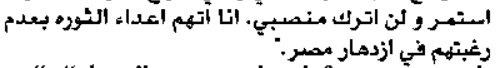

“ "al ra"ees morsi adaf : anả mosh ba"fakar fi "il "stiqala la"ini sawf a"ta7amal al mas"uliya al molqah 3ala 3 atiqi min qabl al sha3b ma3a nihnyat fatrat 7 okmi wa hiya al "arba3 seneen . ana sawf a"stamr wa lan a'trok mansabi wa a'tahim A'3da" al sawra bi3adam ra3"bathom fi " izdihar misr."

It's no secret that 'Al Bernameg' models itself on The Daily Show with Jon Stewart; in fact Youssef himself appeared as a guest on The Daily Show earlier this year and said in an interview on Tuesday, 5th
March 2013 Al Arabia news:

'Jon Stewart is my idol.' The new season takes its cues from Stewart's satirical swipes at Fox News coverage and the trademark segments using politicians' own words against them to show contradiction. The show is also taped in front of a live studio audience, a rarity in Egyptian TV."

In a previous episode, which was abruptly postponed due to the unrest but is available on "Al Bernameg's" YouTube channel, Youssef devotes most of the show to a brutally funny takedown of Morsi, describing the president as "Morsi the uniter of powers.' It is a reference to the Pharaoh Mina 'the uniter of the two realms' who united Upper and Lower Egypt to create one kingdom in the year $3200 \mathrm{BC}$. The joke being that Egypt has become bitterly divided under Morsi's rule. A mock up of the president in full King Tut regalia completes the pun.

Using a variety of montages, graphics, sound effects and props, the half hour segment -- which has yet to be broadcast on TV -- makes frequent use of words like dictator, pharaoh, king, and absolute power.

The show also makes fun of a number of speeches made by the president, calling him 'Super Morsi.' The superhero title is superimposed on an image of the president holding his jacket wide open in front of crowds in. Tahrir, a famous gesture shortly after his election intended to show his fearlessness of appearing in public without a bullet proof vest.

One segment features a series of statements by Morsi cross-cut with similar statements from ousted president Hosni Mubarak. The suspended episode also uses clips from Mursi's TV interviews during the clection campaign. When asked how he would respond if, after being elected, people went out and marched against him, Morsi answered:

"This will not happen, because the president, if that's me, will act in accordance with the will of the people. And if I fail to do so, I will be the first to go down and follow the will of the people." 
هـا لن يعدث لاتي انا الرئيس و هو انا سـوف أعهل

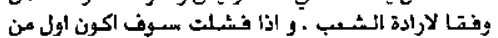
يتازل عن السكم و الاستجابه لرغبه الشغب. "haza lan ya7dos la"ini ana al ra"ees wa huwa ana sawf a"3mal wifqan li"iradat al Sha3b wa I"za fashalt sawf a"koon a"wl man yatanazel 3an a"l7okm wa al I"stigaba li ra3"bat al sha3b."

In another clip Morsi is seen saying:

"I want the people to rise up against me if I don't respect the law or the constitution."

The show does not spare non-Islamists, liberals and revolutionaries from its sharpwitted ridicule. The opposition protesters demonstrating against president Mursi's decree are portrayed as lightweights more concerned with personal hygiene and getting a fresh supply of underwear than hard core protest.

As for the counter rally staged in support of the president's decisions - which called for the implementation of Islamic Sharia - Youssef mocked the spin doctors talking up the numbers:

"In my personal assessment, I think there were 3 or 4 million people, one commentator says in a sound bite. At least 2 million and our brothers say 5 million so on average 3.5 million at least, another says. They say more than six million, a sheikh tells his TV audience. At which point Youssef launches into an auctioneer's voice, gavel in hand, saying 'I hear 7 million, who has 7 million? Do I hear 7.5 million, You sir, in the back, 8 million, thank you, 9 million, who has 10 million?"

Youssef's colleagues aren't immune ejther. In his opening maneuver on the season premicre, he took aim at his fellow hosts who share the airvaves on CBC TV, making fun of some of the most well known faces in Egyptian TV. He also made a point of poking fun at himself for jumping ship from the left leaning On TV. seen as pro-revolution, to the CBC channel, perceived by some to represent the 'felool' or old regime viewpoint. Bags of cash with dollar signs and other props were used on set to mock his fat paycheck.
And in the charged political environment, his parting shot was:

"To those who think they live in this country alone, wake up. To those who think this is a numbers game, wake up. To those who think Egypt will be ruled by one group, wake up. To those who think Egypt is a young child in need of guidance, wake up."

\section{Discourse framework (2)}

In one of the episodes, host Bassem Youssef holds a red, furry pillow with Morsi's image embroidered on it.Bassem said:

"The president understands us. He understands us better than we understand ourselves. He tells us things we never knew,", before cutting to clips of Morsi's long, detailed speeches. Youssef shouts to the camera: mas!"

"It's October 6! Tell us when it's Christ-

Youssef borrows Stewart's fondness for showing photos and video clips to underscore his punchlines.

At one point, he flashes an image of Morsi to his right and says: don't want to piss him off." "NO, not this guy! We الرئيس بيفهنا هو يفهمنا أكثر معا بنفهم نقسنا هور

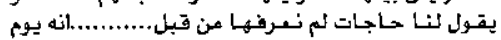

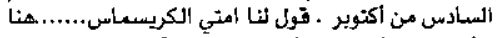

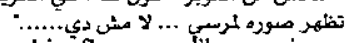

"Al ra"ees biyefhamna a"ksar minma nafham nafsena. Huwa yagool lana 7agat lam na3rifha min qabl . qool lana imta el kirsmas . huna tazhar soora Imorsi la mosh di."

\section{Discourse framew'ork (3)}

If Fairclough (2003) 's appronch of critical discourse analysis is applied on the following text of the introduction of the program, it is found that the words chosen are "satirical,funny, unreal,non-objective ,unbiased" to summarize the main objective of the program and prepare the audience for what is coming or the different segments of the episode. It is a highly -effective technique to attract the audience by the most effective language which is using some words that contradicts the real theme of the program "unbiased-unrealnon-objective "which are true if the audi- ence followed the program. The opening of the program is very attractive by being interactive and lives as well as the uniqueness of the ideas used. You cannot predict or expect the techniques of presenting any idea either through linguistic tools or satirical videos or comic clips or mimicry.

The introduction of "Al Bernameg "is stable in all the episodes of the program.

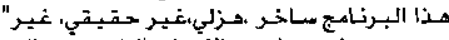

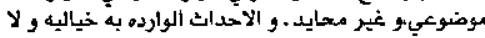

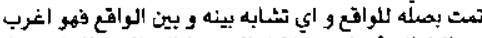

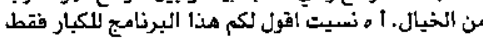

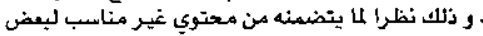

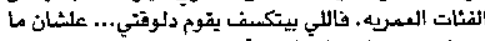
بتنشايقش .. قَومتوا خخلاص.

"haza al bernameg saxer, hazli ,3"er 7aqiqi,3"er mawdoo3i,3"er mu7ayed,wa al "7das al wareda bihi xayaliya wala tamut biSila lil waqi3 , wa ai tashaboh binahu wa bayn al waqi3 fahuwa a3"rab min al xayal . ah nascet aquul lakom . haza al bemameg lil kubar faqat. Wa zalik nazaran lima yatadamanhu min mi7tawa 3"er monaseb liba3d al fia"t al 3omriya . fa illi biyateksef yaqom delwaqti 3 alashan ma yatayeqsh.. qomtu xalaS."

"This program is satirical, funny, unreal, non-objective, unbiased, and all the included events are imaginative and related to reality absolutely. There is no similarity between any event in the program and real life. It is weirder than fantasy. Oh! I forgot to tell you, this program is for grownups only due to the fact that it includes an unsuitable content to some age categories. So, anyone who is shy, he has to leave the screen and go ..Have you moved or not yet?"

The idea that the scriptwriter of the program writes that:

" this program is for grownups only due to the fact that it includes an unsuitable content to some age categories"

The sentence gives the impression that the team of the program challenge you as an audience to prove that it is going to present something serious and not for under-age .The intention here is indirect as it implies that the content includes many unsuitable segments for under age due to the 
degree of freedom of expression that will be expected to be in such program. It is something we have not been used to in our media .Therefore, the following sentence came to be:

"So, anyone who is shy, he has to leave the screen and go ... Have you moved or not yet?"

It is an indication of the mystery that is awaiting those who will dare to proceed watching the content of the program until the end. This is also a new trend or technique of presenting the different problematic issues of the satirical programs by defying the audience to watch.

Bassem uses rhetorical questions in a satirical way as in the following example:

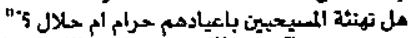
hal tahni"at al masee 7icen fi

3eedohom 7aram am 7alal? “

"Is congratulating the Christians in their feasts accepted religiously or not?"

Foucault (1990) emphasized the existence of a unique relationship among different parties of resistance as belween the Muslims and Christians as well as people and power so if this theory is applied here through the linguistic technique of using rhetorical questions to arouse the curiosity of the audience of the vague issue or controversial casc as the congratulation of Moslems to Christians in their feasts and the legitimacy of such a habit. This question may also imply a moral judgment of such an act.

The satirist Bassem Yousef uses many satirical techniques as the play on words or metonymy by saying "Balbala " then saying "I do not have balall" when he mentioned he is accused by some lawyers of Moslem brother of humilinting religion and the State by mocking religious people and the President. They claim that all his satirical acts cause chaos or distortion which is "balbala " and Bassem played on the word by saying "I am always dry not wet "balall"as I am always wearing Pampers."

The episodes of "Al Bernameg " are characterized by discursiveness of topics as Bassem Yousef moves from one issue to another in a funny or sarcastic techniques using different types of satirical methods as logos , caricature and funny pictures together with high performance of the program team. Grice (1975) is concemed with this distinction between saying and meaning. How do speakers know how to generate these implicit meanings, and how can they assume that their addressees will reliably understand their intended meaning? His aim is to discover the mechanism behind this process. Speakers can convey their intentions by a limitless number of utterances; it is up to the hearer to calculate the speaker's intention. The following segment is a an accurate example of the cooperative theory of Grice as there is an indirect intention about saying such conversation so as to give a certain message which is that Dr Essam El Erian is holding all these official posts which is the same ruling method of the old regime and to give the impression of how much influential he is.

In one of the episodes (13):

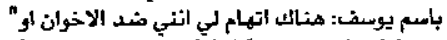

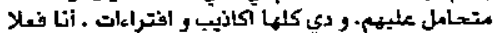

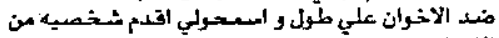

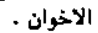
موسيتي تصويري مصاحبه لافيديو كليب.

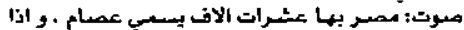

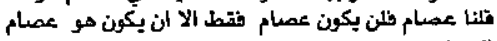

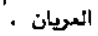

فيديومات مشتوعه لقنوات فنضائيه مختلفه . نائب رئيس حزب الحريه وائداله.

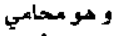
و وحو طبيب و و ومئي و مو منكر سياسي و و مو رئيس نجنة التملاقات الخخارجيه بمجلمس المنعب و و مو مغكر ديني عضو مكتب الارئباد

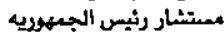
عضو الجعبيه التأسيعيه للدستورد.

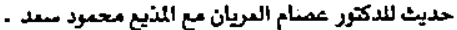

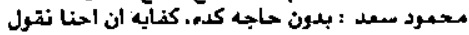
الدكتور عمعام المريان.

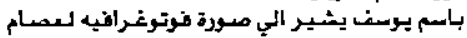

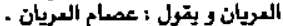

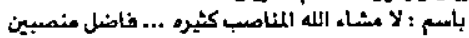

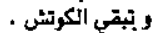
و ويثير الب لمعوره للمعثل غمسان مطر :

“ Basim yusif : hunak "itiham li anani daid al "ixwan "aw muta7amel 3alaihom .

Wa di kulaha "akazeeb wa "iftra"at . "ana fi3lan daid "il "ixwan 3ala Tool wa sam7uni uqadim shaxSiya min "il "ixwan.

Museeka taSweeriya muSahiba lil vidu klib.

Soot: miSr biha 3asharaat al "alaf yusama 3iSam. wa "iza qulna 3iSam faqat "ila an yakoon huwa 3iSam "il 3iryan.

Viduhat mutanawi3a liqanawat faDa"iya muxtalifa.

$\mathrm{Na}$ "ib hizb al al huriya wa al 3adala.

Wa huwa muhami.

Wa huwa Tabeeb.

Wa huwa mufakr syasi.

Wa huwa ra"ees lagnet al 3ilaqat al xarigiya bi maglis al shaab.

Wa huwa mufakr deeni.

3Du maktab al "irshad.mustashar ra"ces al gumhuriya.

3Du al gam3iya al ta"asisiya lil distoor.

7adees lil doktoor 3isam al 3iryan ma3a al muzee 3 mahmood saad.

Mahmood saad : bidoon 7aga kida. Kifaya "in "i7na niqool al doktoor 3isam a"] 3iryan.

Basim yusif yusheer liSoorat foto3"rafiya li3iSam al"iryan wa yaqool : 3iSam a'l 3iryan.

Basim : la mash"a alah al manaSib kaseera.. faDil manSibeen wa tibqa al kotish.

Wa yusheer "ila Soorat lil mumasil 3"san ma'Tar."

“ Bassim Yousif : There is an accusation that I am against the Moslem Brothers or attacking them. These are always lies and allegations. I am really against them all the time and pardon me I am going to present a character of the Moslem Brothers.

Content music accompanies the video clip.

Voice over: Egypt is full with tens of thousands of people named Essam . but if we mentioned Essam ,there is only one which is Essam El Erian.

Different video clips from various Satellite Channels.

Deputy chairman of Freedom and Justice Party.

He is a lawyer.

He is a Doctor.

$\mathrm{He}$ is a political thinker.

$\mathrm{He}$ is head of the foreign affairs committee at people's assembly.

$\mathrm{He}$ is a religious thinker.

Member of the Guiding office of Moslem Brothers.

President advisor. 
Member of the constitution committec. An interview with Dr Essam El Erian with the anchor Mahmoud Satad.

Mahmoud Saad :Without any say. It is enough to say Essam El Erian.

Bassem Yousef points to Photographic photo of Essam El Erian and mentions his name.

Bassem : God save him for having many posts. He is only missing two posts to be a couch . Bassem points to the photo of the famous actor Ghassan Mattar."

\section{Discourse ( $f$ )}

In another episode, Bassem talks about motherhood and gives a unique metaphor of the government saying:

"Bassem : We are the sons of the government... all its resolutions for our welfare.. They are sharing our fears. They fear for our benefits...Mama ...I mean the government of Hisham Qandil that by cutting the electricity, we will sleep early every night."

This segment is followed by different videos from various Satellite channels to comment on what Bassem said earlier.

" Khairy Ramadan (a famous Egyptian anchor at CBC) said :They (government officials) will make secret rooms for us ."

Bassem moves into another segment of his program to talk abouy the loaf of bread of the government. He presents different commentaries from various TV channels.

"Mahmoud Saad (Famous anchor in Al Naahar TV )said: Every one must eat three loafs of bread every day."

A magnified photo of a very huge loaf of bread appeared in Bassem 's hand as an indicator of the new idea of an Islamic loaf of brend "halal" as it was suggested like everything in the state by the Moslem Brothers to solve the bread problem.

A video clip follows of an Islamic TV Channel saying:

"There is an Islamic baking powder ready made by the Mostem Brothers to solve all the cconomic problems in Egypt."

\section{Discourse (5)}

In the episode aired on the 1ST March 2013, all what we want say or speculate on what's going on Egypt was said. In one of the recorded video clips of the President
Mohamed Morsi, the fifth in rule the first elected president afier the January revolution, addressing the nation and beside him stands the spiritual leading figure of the Moslem Brothers Dr Mohamed Badic spelling him out the word that he wants Morsi to say "retribution". In a very sarcastic tone Bassem commented afier this clip on the funny and satirical situation.

By unleashing a deluge of satire on Egypt's leaders - to greal comic effect Youssef is not only making light of the situation but also openly questioning authority and holding elected officials to account.

\section{V.Conclusion}

For a brief moment on cvery Friday night, Egyptians got some relief from the ongoing political crisis tearing the country apart by watching Bassem Youssef's satirical- comic news show "Al Bernameg" (The Progrum).

For all the laughs, the latest episode ended on a serious note. After spending more than an hour making light of the deep divisions in Egyptian society. Youssef told his viewers: "We are not the oncs shlo turned this into us versus them; we are not the ones who tumed a political conflict into a battle between heaven and hell. It is others who have turned this into Muslims versus Infidels."

And in the charged political environment. his parting shot wals: "To those who think they live in this country alone, wake up. To those who think this is a numbers game, wake up. To those who think Egypt will be ruled by one group, wake up. To those who think Egypt is a young child in need of guidance, wake up."

Creating satire is no ealsy lask. and the El Bernameg team dedicates long hours to researching, archiving and locating patterns in the media footage that they monitor.

Forming an understanding of how satire is used to convey a message, this study also contributes to a deeper level of understanding of language and culture needed for effective communication. By exploring examples of Foucault's concept of power in "Al Bernameg", the satirical discourses are revealed as more than just a cartoon and its humor. This study illustrates also how satire can function as resistance to au- thority by broadening an awareness of the role that humor can play in giving people a voice to resist power, to express criticism, and to begin to work for a better society.

Language is used creatively in satirical discourse programs as Bassem Yousef's "Al Bernameg". Language play in such programs involves imogination, fiction and humorous video clips. Language play is manifested in the parody of the different funny interviews by the men of power and the commentary as well as repetition of their speeches in a humoristic style. Satirical techniques as exaggeration, ironies, metaphors and imitation of the performance of the President and government officials as well as reversals cannot be presented in a political satirical talk show without play on words and using of twisting language to be more effective on the target audience. Such programs play a crucial and focal role in societies especially during political crises and represent a new trend in media full of freedom of expression but there must be some control on the expediency of information and material so as to check its credibility and accuracy bcfore airing.

\section{Appendix}

List of Symbols of Arabic Phonemic Transcription

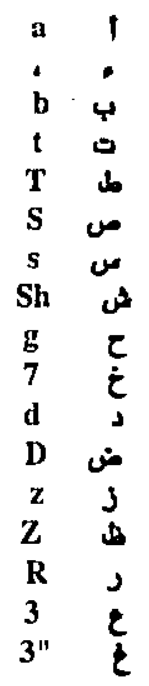




$\begin{array}{ll}\text { f } & \text { i } \\ \text { q } & 3 \\ \text { k } & 4 \\ \text { L } & \text { J } \\ \text { m } & \text { p } \\ \text { n } & \dot{v} \\ \text { h } & : \\ \text { w } & \text { g } \\ \text { y } & \mathbf{s}\end{array}$

Notes

1. (Entman, 1993, 2004). Framing works to shape and alter audience members' interpretations and preferences through priming.

That is, frames introduce or raise the salience or apparent importance of certain ideas, activating schemas that encourage target audiences to think, fcel, and decide in a particular way (see, e.g., Gross \& D'Ambrosio, 2004; lyengar \& Simon, 1993; Kim,

Scheufele, \& Shanahan, 2002; Price, Tewksbury, \& Powers, 1997).The strategic framing contests that occupy the heart of the political process take place in the first instance over the agenda (Riker, 1986). Agenda setting can thus be scen as another name for successfully performing the first function of framing:defining problems worthy of public and government attention. Among other things, agenda problems can spotlight societal conditions, world events, or character traits of a candidate. The second or "attribute" level of agenda setting (McCombs \& Ghanem, 2001) centrally involves three types of claims that happen to encompass the core business of strategic framing: to highlight the causes of problems, to encourage moral judgments (and associated affective responses), and to promote favored policies. Priming, then, is a name for the goal, the intended effecl, of strategic actors'framing activities. The oft-quoted but misleading phrase that inaugurated the modern study of media effects is that: "the media may not be successful much of the time in telling people what to think, but is stunningly successful in telling its readers what to think about" (Cohen, 1963, p. 13, emphasis in original). Although the distinction between "what to think" and "what to think about" is not entirely clear, the former seems to mean what people decide, favor, or accept, whereas the latter refers to the considerations they "think about" in coming to such conclusions. The distinction misleads because, short of physical coercion, all influence over "what people think" derives from telling them "what to think about." If the media really are stunningly successful in telling people what to think about, they must also exert significant influence over what they think.

\section{The Cooperative Principle}

"Make your contribution such as required, at the stage at which it occurs, by the accepted purpose or direction of the talk exchange in which you are engaged"Grice (1975:45)

The Maxims

Quantity Make your contribution as informative as is required

Do not make your contribution more informative than is

required

Quality Do not say what you believe to be false

Do not say that for which you lack adequate evidence

Relation Be relevant

Manner Avoid obscurity of expression

Avoid ambiguity

3. Fairclough (2003: 26) has dclineated three characteristics of discourse which describe its operation within social life, as 'part of the action.' These are;

- Genres (ways of acting)

- Discourses (ways of representing)

- Styles (ways of being)

'Genres' refer to a particular way of manipulating and framing discourse; examples of genres are church sermons, interviews and political speeches. Genres are significant because they provide a framework for an audience to comprehend discourse, though evidently due to this quality, 'genres' can be the locus of power, domination and resistance. 'Discourses/representation' is crucial in assessing the means by which apparently similar aspects of the world can be appreciated and understood from different perspectives or positions. Finally, 'styles' are the ways in which discourse is used to constitute a sense of being and identity, how identification is located through the application and manner of particular discourses.

\section{References}

Alberti, J. 2003. Leaving Springfield: The Simpsons and the possibility of oppositional culture. Detroit: Wayne State University Press. Retrieved March 26, 2009, from http:/l books.google.com/books?id=n6vZJnxK1XYC

Basu,S.(1999). "Dialectic Ethics and the virtue of Humor".Joumal of Political Philosophy.New York: Albany.

Entman,R.(2004) Projections of Power: Framing News,Public Opinion, and US Foreign Policy.London: University of Chicago.

Fairclough, N. (1992) Discourse and Social Change. Polity Press. Cambridge.

Fairclough, N. (1995) Critical Discourse Analysis. Longman. London.

Fairclough, N. (2003) Analysing Discourse: Textual analysis for social research. New York and London. Routledge.

Foucault, M. (1980) Power/Knowledge: selected interviews and other writings 1972-1977. Edited by C. Gordon. Brighton. Harvester Press.

Grice, H. P. (1975). Logic and Conversation.

In Martinich, A.P. (ed). Philosophy of Language.(pp. 165-175) New York, NY: Oxford University Press.

Moreall,J.(1983).'Taking laughter seriously".Journal of Political Philosophy.NY: Albany.

Pickett, B. 2006. Foucault and the politics of resistance. Polity, 28(4), 445-466. Retrieved 2 July 2011 , from http://experiment.iitalia.com/ librarysplit2/JSTOR\%20Pickett\%20-

$\% 20$ Foucault $\% 20$ And $\% 20$ The\%20Politics $\% 200$ f\%20Resistance.pdf

Rabinow, P. (Ed.). 1984. The Foucault reader. New York: Penguin Books.

Simpson,P.(2003) On the Discourse of Satire :Towards a stylistic Model of Satirical Humor.Amsterdam: John Benjamins. 